\title{
HUBUNGAN PENGETAHUAN IBU TENTANG GIZI DENGAN GEJALA ANEMIA IBU HAMIL DI RUMAH BERSALIN MARIANI MEDAN
}

\author{
Relationship Capital Knowledge About Nutrition In Symptoms \\ Anemia Pregnancy At Home maternity Mariani Medan
}

\author{
Nurleli \\ Dosen Tetap Yayasan Akper Kesdam I/BB Medan \\ email: nurlelialbahani@yahoo.com
}

\begin{abstract}
ABSTRAK
Anemia pada kehamilan sering disebabkan oleh poor nutrition, defisiensi zat besi dan infeksi malaria. Sebagaimana diketahui bahwa pada kehamilan kebutuhan zat besi meningkat karena perubahan fisiologis dadn metabolisme. Maka dampak dari anemia padaibu hamil akan menyebabkan rendahnya kemampuan jasmani karena sel-sel tubuh tidak cukup mendapatkan oksigen,meningkatkan frekuensi komplikasi pada kehamilan dan persalinan. Hal ini akan beresiko kematian maternal, angka prematuritas, BBLR dan angka kematian perinatal meningkat.

Tujuan dari penelitian ini adalah untuk mengetahui seberapa jauh hubunganan pengetahuan ibu tentan gizi dengan gejala anemia ibu hamil. Jenis penelitian yang digunakan dalam penelitian ini adalah deskriptif korelasi dengan menggunakan desain studi cross sectional. Teknik pengambilan sampel pada penelitian ini adalah purposive sampling, jumlah sampelpenelitian ini adalah 40 orang.

Hasil penelitian diuji Chi Square dengan uji statistik diperoleh nilai $p=0,002$ yang berati $p<0,05$. Angka korelasi berkisar antara $0 \mathrm{~s} / \mathrm{d} 1$. Signifikasi hubungan dua variabel dapat dianalisis dengan ketentuan jika $P<0,05$ hubungan signifikan, jika $P>0,05$ hubungan tidak signifikan. Selanjutnya ditemukan hubungan pengetahuan ibu tentang gizi dengan gejala anemia ibu hamil hasil uji statistik diperoleh nilai $\mathrm{p}=0,002$ yang berati $\mathrm{p}<0,05$ maka dapat disimpulkan bahwa ada hubungan pengetahuan ibu tentang gizi dengan gejala anemiaibu hamil di Rumah Bersalin Mariani Medan Tahun 2015. Saran dari peneliti diharapkan kesadaran dari ibu hamil sendiri untuk mengunjungi petugas kesehatan didaerah tempat tinggalnya guna memperoleh informasi tentang gizi pada ibu hamil agar mencegah terjadinya anemia pada ibu hamil
\end{abstract}

Kata kunci : Pengetahuan, Anemia, ibu hamil

\begin{abstract}
Anemia in pregnancy is often caused by poor nutrition, iron deficiency and malaria infection. As we know that in pregnancy the need for iron increases due to physiological changes dadn metabolism. Then the impact of anemia padaibu pregnancy will cause poor physical ability for the body's cells do not get enough oxygen, increases the frequency of complications in pregnancy and childbirth. This would risk of maternal mortality, the rate of prematurity, low birth weight and perinatal mortality rate increased. The purpose of this study was to determine how far hubunganan tentan nutritional knowledge of mothers with symptoms of anemia in pregnant mothers. This type of research used in this research is descriptive correlation using cross sectional study design. The sampling technique in this research is purposive sampling, the number is 40 people sampelpenelitian

Results of the study were tested Chi Square statistical test obtained by value $\mathrm{p}=0.002$ which means $p<0.05$. Figures correlation ranged from $0 \mathrm{~s} / \mathrm{d} 1$. Significance relationship between two variables can be analyzed with the provision that if $\mathrm{P}<0.05$ significant relationship, if $\mathrm{P}>0.05$ correlation was not significant. Furthermore, the mother discovered the relationship of knowledge about nutrition of pregnant women with symptoms of anemia statistical test results obtained by value $p=0.002$ which means $p<0.05$, it can be concluded that there is a relationship with the mother's knowledge about nutrition anemiaibu symptoms pregnant at the maternity hospital Mariani Year 2015 Terrain Suggestions of the researchers expected the awareness of his own pregnant women to visit health workers area where he lived in order to obtain information about nutrition in pregnant women to prevent anemia in pregnant women.
\end{abstract}

Keywords: Knowledge, Anemia, pregnant women 


\section{Pendahuluan}

Status gizi ibu selama hamil dapat mempengaruhi pertumbuhan janin yang sedang dikandung. Bila status gizi ibu normal pada selama hamil kemungkinan besar akan melahiran bayi yang sehat, cukup bulan dengan berat badan normal. Dengan kata lain kualitas bayi yang dilahirkan sangat tergantung pada keadaan gizi ibu selama hamil (Zulhaida, 2007). Namun masih banyak terdapat masalah tentang gizi pada ibu hamil, terutama adalah kekurangan gizi, yang penyebabnya adalah multifactor salah satunya adalah pengetahuan tentang gizi itu sendiri.

Dinegara berkembang, termasuk indonesia, masalah gizi merupakan masalah kesehatan masyarakat yang utama dan merupakan penyebab kematian ibu dan anak secara tidak langsung yang sebenarnya masih dapat dicegah. Selain dari penyebab utama yaitu inadequate intake, pengetahuan ibu tentang gizi juga mempengaruhi terjadinya anemia, ini terkait dengan pola kosumsi makanan, sumber-sunber gizi dalam makanan. Menurut Arisman (2004) dengan pengolahan aneka ragam bahan makanan, kekurangan zat gizi pada bahan makanan yang satu dapat dilengkapi oleh jenis bahan makanan lainnya. Bahan makanan yang dikomsumsi hendaknya terdiri atas sumber energi, protein, (hewani dan nabati), vitamin, asam folat, dan zat besi yang bersumber dari susu, roti dan biji-bijian, serta buah dan sayur. Jika seluruh bahan makanan ini digunakan dan diolah dengan baik maka seluruh zat gizi yang di butuhkan akan terpenuhi dan anemia inadequate intake tidak terjadi (Arisman, 2004).

Badan kesehatan dunia (WHO) melaporkan bahwa prepalensi ibu-ibu hamil yang mengalami defesiensi besi sekitar 35-75\%, serta semangkin meningkat dengan pertambah usia kehamilan. Di indonesia anemia pada kehamilan masih tinggi yaitu sekitar $40,1 \%$, dari 31 orang wanita hamil pada trisemester II didapati 23 orang (74\%) menderita anemia, dan 13 orang (42\%) menderita kekurangan zat besi (SKRT 2001). Penelitian SKRT 2001 yang diadakan di beberapa praktek bidan swasta dalam kotamadya Medan, ditemukan bahwa terjadi peningkatan penderita anemia. Besarnya angka kejadian anemia ibu hamil pada trimester I kehamilan adalah $20 \%$, trimester II sebesar 70\%, trimester III sebesar 70\%. (http / library. Usu. Id, 2007) Kebutuhan ibu hamil gizi sangat meningkat, dimana gizi tersebut sangat penting untuk membantu pembentukan sel darah merah. Namun yang sering terjadi ibu hamil cenderung mengalami kekurangan gizi, seperti kekurangan zat besi, asam folat, vitamin B12 dan vitamin $\mathrm{C}$, juga kekurangan protein, sehingga terjadi anemia pada kehamilan. Banyak ibu hamil yang menderita kekurangan gizi secara terus menerus berdampak pada keguguran, pendarahan, dan pada anak dapat lahir premature dan berat badan lahir rendah, bahkan dapat terjadi kematian ibu maupun anak sebelum lahir. (Scholl, 2005).

Menurut Tarwoto (2007) kekurangan zat besi pada ibu hamil dapat mengakibatkan keguguran, lahir sebelum waktunya, berat badan lahir rendah, perdarahan sebelum dan selama persalinan bahkan dapat mengakibatkan kematian pada ibu dan janin.

Menurut Wibowo (2007) kekurangan asam folat pada ibu hamil dapat menyebabkan terjadinya kecacatan pada bayi yaang dilahirkannya. Bayi dapat mengalami cacat pada otak dan sumsum tulang belakang.

Menurut Borck K (2007) kebutuhan vitamin B12 adalah 2,2 $\mu \mathrm{g}$. Bila kekurangan vitamin B12 mengakibatkan anemia karena kekurangan folat, gangguan sintesis DNA, dan degenerasi otak. Fungsi vitamin $\mathrm{C}$ dalam tubuh adalah sebagai antioksidan dan membantu absorpsi juga metabolisme besi dalam tubuh. sedangkan protein juga diperlukan plasenta untuk membawa makanan ke janin dan juga pengaturan hormon sang ibu dan janin.

Menurut Prasetyono (2009) kekurangan vitamin C pada ibu hamil bisa menyebabkan terjadinya pre eklapsia serta keguguran yang didahului dengan pecahnya ketuban sebelum waktunya.

Gejala anemia pada ibu hamil juga dapat menyebabkan rendahnya kemampuan jasmani karena sel-sel tubuh tidak cukup mendapat oksigen, sehingga frekuensi komplikasi pada kehamilan dan persalinan juga meningkat, seperti terjadinya resiko kematian ibu, angka prematuritas atau abortus, BBLR, dan angka kematian perinatal meningkat. (Achadi, dkk, 2007)

Pre survey yang dilakukan peneliti pada bulan Juli Tahun 2015 Di Rumah Bersalin Mariani Medan, terdapat 45 orang yang memeriksakan kehamilan didapati 19 ibu yang mengalani anemia, saat dilakukan pemeriksaan kadar $\mathrm{Hb}<11$ gr/dl. Dengan keluhan lemah, letih, lesu dan pandangan berkunang kunang,saat dilakukan pemeriksaan fisik terdapat konjungtiva yang pucat. 17 orang ibu dari data dokumentasi 2014-2015 didapati 6 orang ibu mengalami kematian janin dalam kandungan (KJDK), 4 orang bayi dengan berat badan lahir rendah (BBLR) serta 7 orang ibu yang mengalami retensio plasenta. 7 orang $\mathrm{ibu}$ dari data dokumentasi pada bulan juni Tahun 2009 didapati 2 orang ibu yang mengalami ketuban pecah dini (KPD), 2 orang ibu yang mengalami kematian janin dalam kandungan (KJDK), 3 orang ibu mengalami retensio plasenta. Hasil wawancara terhadap 10 orang ibu yang mengalami anemia tersebut didapati pengetahuan yang kurang tentang gizi dan anemia.

\section{Perumusan masalah}

Berdasarkan latar belakang yang diuraikan diatas, maka peneliti merumuskan permasalah 
seberapa erat hubungan antara pengetahuan ibu tentang gizi dengan kejadian anemia ibu hamil di Rumah Bersalin Mariani Medan 2015.

\section{Tujuan Penelitian}

\section{Tujuan umum}

Mengetahui seberapa jauh hubungan antara pengetahuan ibu tentang gizi dengan kejadian anemia.

\section{Tujuan khusus}

1. Mengetahui pengetahuan ibu tentang gizi selama kehamilan.

2. Mengidentifikasi gejala anemia kehamilan

3. Mengetahui hubungan pengetahuan ibu tentang gizi dengan terjadinya gejala anemia selama kehamilan

\section{Metode Penelitian}

\section{A. Waktu dan Tempat Penelitian}

Penelitian dilaksanakan mulai bulan Juli 2015 di Rumah Bersalin Mariani Medan

\section{B. Populasi dan Sampel}

1. Populasi

Populasi dalam penelitian ini adalah seluruh ibu hamil yang memeriksakan kehamilannya ke Rumah Bersalin Mariani Medan Selama penelitian berlangsung.

\section{Sampel}

Sampel dalam penelitian ini adalah ibu-ibu yang memeriksakan kehamilan di Klinik Mariani Medan yang mengalami anemia. Teknik pengambilan sampel pada penelitian ini adalah purposive sampling, sebanyak 40 orang dengan kriteria : ibu yang bersedia, dapat membaca dan menulis, serta $\mathrm{Hb}<11 \mathrm{~g} / \mathrm{dl}$. Penentuan jumlah sampel adalah total sampling. Seluruh ibu hamil yang $\mathrm{Hb}<11$ yang ada saat itu.

\section{C.Teknik Pengumpulan Data}

Data yang digunakan dalam penelitian ini adalah data primer. Pengumpulan data diperoleh dengan mengisi lembar observasi yang berisi data diri ibu hamil.

\section{Instrumen penelitian}

Alat pengumpulan data berupa kuesioner dan pengukuran $\mathrm{Hb}$ dengan mengunakan tabung sahli yang disusun oleh peneliti dengan berpedoman pada kerangka konsep dan tinjauan pustaka. Setelah dimodifikasi terlebih dahulu, instrumen ini terdiri dari 4 bagian yaitu : kuesioner data demografi, ibu hamil, pengetahuan ibu tentang gizi, serta gejala anemia yang dialami ibu selama hamil.Kuesioner data demografi terdiri dari usia, pendidikan, pekerjaan. Data ibu hamil terdiri dari paritas, usia kehamilan dan jumlah pemeriksaan kehamilan

\section{E. Pengolahan dan Analisa Data}

Teknik pengolahan data pada penelitian ini dilakukan dengan menyusun data yang diperoleh kemudian diklasifikasikan dan diberi kode sesuai bahasa komputer (SPSS), dan untuk analisanya dengan menggunakan Uji Chi Square

\section{Hasil Penelitian}

Berdasarkan hasil penelitian hubungan pengetahuan ibu tentang gizi dengan gejala anemia ibu hamil terhadap 40 orang responden didapatkan hasil sebagai berikut :.

1. usia

Sebagian besar (85\%) ibu hamil berusia antara 20 - 30 tahun, usia 31 - 40 tahun $(26,7 \%)$, table 3 . Distribusi Frekuensi usia Ibu hamil di Rumah Bersalin Mariani Medan Juli - September 2015 Usia Frekuensi Prosentase

20 - 303485

$31-40 \quad 615$

Jumlah 40100

\section{Tingkat Pendidikan}

Sebagian ibu hamil berpendidikan SMP $(37,5 \%)$ dan yang berpendidikan S1 $(2,5 \%)$.

Distribusi Frekuensi Menurut Pendidikan Ibu hamil di Rumah Bersalin Mariani Medan Juli September 2015 Frekuensi Prosentase

SMP 15 37,5

SMU 1947,5

DIII 512,5

SI 12,2

Jumlah 40100

\section{Pekerjaan}

Sebagian besar $(77,5 \%)$ ibu hamil bekerja sebagai bu rumah tangga (IRT), yang lainnya bekerja di perusahaan swasta dan berwiraswasta. Distribusi Frekuensi Menurut Pekerjaan Ibu hamil di Rumah Bersalin Mariani Medan Juli - September 2015 Frekuensi Prosentase

IRT 3177,5

Wiraswasta 820

Pegawai swasta 12,5

Jumlah 40100

4. Usia kehamilan

Sebagian besar $(37,5 \%)$ usia kehamilan pada Trimester III (25-36 minggu), yang lainnya pada Trimester II dan Trimester I. Distribusi Frekuensi Menurut Pekerjaan Ibu hamil di Rumah Bersalin Mariani Medan Juli - September 2015 Frekuensi Prosentase

Trimester I 12,5

Trimester II 1540

Trimester III 24 37,5

5.Pemeriksaan kehamilan 
Sebagian besar ibu hamil memeriksakan kehamilannnya $<3$ kali $(92,5 \%)$ dan selainnya > 3 kali. Distribusi Frekuensi Pemeriksaan Kehamilan Ibu di Rumah Bersalin Mariani Medan Juli September 2015 Frekuensi Prosentase

$<3$ kali 32 92,5

$<3$ kali 87,5

6. Heart Rate

Sebagian besar Heard Rate ibu hamil 84x/m (40\%) dan yang lainnya tertera pada tabel Distribusi Frekuensi Pemeriksaan Kehamilan Ibu di Rumah Bersalin Mariani Medan Juli - September 2015 Frekuensi Prosentase

$80 \mathrm{x} / \mathrm{m} 410$

$84 \mathrm{x} / \mathrm{m} 1127,5$

$88 \mathrm{x} / \mathrm{m} 1640$

$90 \mathrm{x} / \mathrm{m} 512,5$

$92 \mathrm{x} / \mathrm{m} 410$

7. Tekanan darah sistolik

Sebagian besar tekanan darah sistolik $120 \mathrm{mmHg}$ $(42,5 \%)$ dan yang lainnya $120 \mathrm{mmHg}$ dan 130 $\mathrm{mmHg}$. Distribusi Frekuensi tekanan darah sistolik ibu hamil di Rumah Bersalin Mariani Medan Juli September 2015 Frekuensi Prosentase

$110 \mathrm{mmHg} 1127,5$

$120 \mathrm{mmHg} 1742,5$

$130 \mathrm{mmHg} 1230$

8. Tekanan darah diastolik

Sebagian besar tekanan darah diastolik $80 \mathrm{mmHg}$ (60\%) dan yang lainnya $70 \mathrm{mmHg}$ dan $90 \mathrm{mmHg}$. Distribusi Frekuensi tekanan darah diastolik ibu hamil di Rumah Bersalin Mariani Medan Juli September 2015 Frekuensi Prosentase

$70 \mathrm{mmHg} 1435$

$80 \mathrm{mmHg} 2460$

$90 \mathrm{mmHg} 25$

\section{Kadar hemoglobin}

Sebagian besar kadar hemoglobin $>11 \mathrm{mg} \%(67,5)$ dan yang lainnya $<11 \mathrm{mg} \%$. Distribusi Frekuensi kadar hemoglobin ibu hamil di Rumah Bersalin Mariani Medan Juli - September 2015 Frekuensi Prosentase

$<11 \mathrm{mg} \% 1332,5$

$>11 \mathrm{mg} \% 2767,5$

\section{Status Anemi}

Sebagian besar ibu hamil tidak anemi $(67,5 \%) \mathrm{k}$ dan yang lainnya anemi. Pada tabel 4 Distribusi Frekuensi status anemia ibu hamil di Rumah Bersalin Mariani Medan Juli - September 2015 Frekuensi Prosentase

Anemi 13 32,5\%

Tidak anemi 27 67,5\%

11. Tingkat pengetahuan ibu
Tingkat pengetahuan ibu mengenai sumber gizi, pengolahan makanan dan pola komsumsi adalah sebagian besar pengetahuan ibu hamil baik $(50 \%) \mathrm{k}$ dan yang lainnya cukup dan kurang. Pada tabel 8 , Distribusi Frekuensi tingkat pengetahuan ibu hamil di Rumah Bersalin Mariani Medan Juli September 2015 Frekuensi Prosentase

Baik 2050

Cukup 1127,5

Kurang 922,5

Pembahasan

Pengetahuan ibu tentang gizi dengan gejala anemia ibu hamil Tabel 9. Hubungan Pengetahuan ibu tentang gizi dengan gejala anemia ibu hamil di Rumah Bersalin Mariani Medan 2015. Menunjukkan mayoritas tingkat pengetahuan ibu baik yaitu sebanyak 20 orang (50\%), cukup sebanyak 11 orang $(27,5 \%)$ dan kurang sebanyak 9 orang $(22,5 \%)$. Hal ini kemun gkinan disebabkan tingkat pendidikan responden mayoritas SMA 19 orang $(47,5 \%)$, DIII 5 orang $(12,5 \%)$, sarjana 1 orang $(2,5 \%)$ dan minoritas SMP 15 orang $(37,5 \%)$

\section{Simpulan}

Berdasarkan hasil analisa dan pembahasan yang telah diuraikan sebelumnya, dapat ditarik kesimpulan sebagai berikut :

1. Sebanyak 4 dari $9 \quad(44,4 \%)$ ibu hamil mengalami anemia dengan tingkat pendidikan kurang, ada 6 dari $11(54,5 \%)$ ibu yang mengalami anemia dengan tingkat pendidikan cukup dan ada 3 dari 20 (15\%) ibu yang mengalami anemia dengan tingkat pendidkan baik

2. Terindentifikasi bahwa gejala anemia kehamilan di Rumah Bersalin Mariani Medan tahun 2015, mayoritas ibu tidak anemi yaitu sebanyak 27 orang $(67,5 \%)$ dan ibu yang mengalami anemia 13 orang $(32,5 \%)$

3. Ada hubungan pengetahuan ibu tentang gizi dengan gejala anemia selama kehamilan di Rumah Bersalin Mariani Medan 2015.

\section{Daftar Pustaka}

Ahmadi (2007), Gizi Ibu dan Kesehatan Reproduksi : Gizi dan Kesehatan Masyarakat,PT Raja Grafindo Persada, Jakarta.

Amatsier (2006), Prinsip Dasar ilmu Gizi, Gramedia Pustaka Utama, Jakarta

Asman (2004), Gizi Dalam Daur Kehidupan:Anemia Defisiensi Zat Besi,EGC,Jakarta

Arief (2007),Prevalensi Anemia Pada Hamil, Cermin Kedokteran,http//: www

Arikunto (2007), Manajemen Penelitian,Metodelogi Pendekatan, EGC,Jakarta 
Bizard (2000), Effectiveness And Strategis Of Iron Suplementation During Pregnancy,American JournalOf Clinical Nutrition.

Bork dkk (2000), Etiologi Of Anemia In Pregnancy, American Journal Of Clinical Nutrition

Iriansyah (2002), Status Serum Zink Ibu Hamil: Unhas, Bogor

Kasmanto (2008), Pola Komsumsi Ibu Hamil, http//:www,infosehat.com

Katinah,dkk(2005), Anemia Ibu Hamil dan FaktorFaktor Yang Mempengaruhi Serta Dampaknya Pada Berat Bayi Lahir di Kecamatan Medan Tuntungan Kota Madya Medan

Kozier dkk (2006), Nutrition : Concepts and Controversies, Tenth Edition, Thomson wadworth USA

Mubarak Iqbal Wahid dkk (2006) Buku Ajar Ilmu Keperawatan Komunitas 2, Agung Seto, Jakarta.

Notoatmodjo, (2005) , Metodelogi Penelitian Kesehatan, Jakarta, Rineka Cipta

Nursalam (2008),Konsep dan Penerapan Metodelogi Penelitian Ilmu Keperawatan Pedoman Skripsi, Tesi dan Instrumen Penelitian Keperawatan,Salemba Medika, Jakarta

Prasetyono (2009), Mengenal Menu Sehat Ibu Hamil, DIVA Press (Anggota IKAPI), Jogjakarta

Rolfes (2006), Understanding Normal And Clinical Nutrition,seventh edition : Thomson Wadworth USA

http/www.library.usu.ac.id,2007,AnemiaDef isiensi Besi Pada Wanita Hamil di Beberapa Praktek Bidan Swadaya dalamKotamadya Medan

Rosmeri (2005), Makanan Yang Aman Untuk Kehamilan.Tanpa Kota : TanpaPenerbit -http/www.balita.com, Faktor Resiko Kejadian anemia pada Ibu Hamil.

Samuel (2006), Gizi Sehat Selama Kehamilan, http//:www.gizinet.com

Sarwono (2003), Ilmu Kandungan, edisi Revisi, EGC, Jakarta

Setiadi (2007), Konsep dan Penulisan RisetKeperawatan,Edisi Pertama,Graha Ilmu, yogyakarta

Scholl (2005), Iron During Pregnancy : Setting the stage for mother and infant,American Journal of clinical nutrition

Sudharma dkk (2003), Effect Of Dietary Habits on Prevalency of Anemia in Women,journal of Obstetric and Gynaecology Research

Sudjana(2002), Metoda Statiska, Penerbit PT. Tarsito bandung
Tarwoto (2007), Buku Saku Anemia Pada Ibu Hamil, Konsep dan Penatalaksanaan,EGC,Jakarta

Wibowo (2007), Faktor Resiko prevalensi Anemia dan Faktor-faktor yang Berpengaruh Terhadap Kejadian Anemia Pada Ibu Hamil, http//:www.homeprogramgizianemia.coml

Zulhaida (2007), faktor-Faktor yang Berhubungan Dengan Rendahnya cakupan Fe Ibu Hamil, http//:www.pksplus.com 